\title{
IMPLEMENTASI MODEL PEMBELAJARAN MAKE A MATCH BERBASIS KEARIFAN LOKAL UNTUK MENINGKATKAN HASIL BELAJAR KOGNITIF SISWA
}

\author{
Jayanik Mayasari $^{1}$, Murtono $^{2}$, Imaniar Purbasari $^{3}$ \\ ${ }^{1,2,3}$ Universitas Muria Kudus, Jl. Lkr. Utara, Kayuapu Kulon, Gondangmanis, Kec. Bae, Kab. Kudus, Jawa Tengah 59327 \\ Jmayasari89@gmail.com
}

\begin{abstract}
Education cannot be interpreted only as science implementation, but it is broader. By implementing proper education, learners will also understand local wisdom in their surrounding environment. This research takes local wisdom in Kudus as Hindu, Buddist, and Islam heritages. This research aim to find out the implementation of Make A Match learning model based on local wisdom toward the cognitive learning outcames of learners. This research applice classroom action method promoted in two cycles. Each cycle consisted of four stages: 1) planning; 2) acting; 3) observing; 4) monitoring. The finding showed that Make A match model based on local wisdom could improve cognitive leraners' learning outcames. It could be seen from the reached indicators as follow. Cognitive learning outcame improvement improved with a pre-cycle score achievement of social suty lesson $52,63 \%$ it improved into $68,42 \%$ in cycle I then, it improved in cycle II $84,21 \%$. Meanwhile, dealing with Indonesian language content, it improved from $68,15 \%$ in pre-cycle into $73,6 \%$ in cycle I then, in cycle II it improved into $89,47 \%$
\end{abstract}

Keywords: Learning Outcomes, Make A Match, Local wisdom

\begin{abstract}
Abstrak
Pendidikan tidak dapat ditafsirkan hanya sebagai implementasi ilmu pengetahuan saja, melainkan harus lebih luas sehingga para siswa memiliki pemahaman terhadap kearifan lokal daerah setempat. Penelitian ini mengangkat kearifan lokal yang ada di Kudus berupa peninggalan berkaitan dengan kerajaan Hindhu, Buddha dan Islam. Tujuan dari penelitian ini adalah untuk mengetahui peningkatan dari implementasi model pembelajaran Make A Match berbasis kearifan lokal terhadap hasil belajar kognitif siswa. Penelitian ini menggunakan metode penelitian tindakan kelas PTK yang dilakukan sebanyak 2 siklus dimana masing-masing siklus dilakukan dengan empat tahapan yaitu: 1) perencanaan, 2) pelaksanaan, 3) observasi, 4) pengamatan. Hasil penelitian ini menunjukkan bahwa melalui pembelajaran model Make A Match berbasis kearifan lokal dapat meningkatkan hasil belajar kognitif siswa. Hal ini dapat dilihat dari terpenuhinya indikator keberhasilan sebagai berikut. Peningkatan hasil belajar ranah pengetahuan meningkat dengan perolehan nilai prasiklus muatan IPS 52,63\% meningkat menjadi $68,42 \%$ siklus I dan siklus II 84,21\%. Sedangkan pada muatan Bahasa Indonesia dari 68,15\% pada prasiklus menjadi 73,68\% siklus I dan siklus II menjadi 89,47\%.
\end{abstract}

Kata kunci: Hasil Belajar, Make A Match, Kearifan Lokal

Pada era globalisasi ini, sangat menuntut adanya sumber daya manusia yang berkualitas. Adapun upaya dalam menghasilkan sumber daya manusia yang berkualitas ialah dengan adanya pendidikan melalui proses pembelajaran. Daryanto dan Muljo Rahardjo (2012: 30) berpendapat bahwa pembelajaran merupakan proses interaksi antara komponen-komponen dalam sistem pembelajaran. Kegiatan pembelajaran juga merupakan sebuah kunci utama dalam proses pendidikan disekolah, dengan guru sebagai peranan utama dalam kegiatan pembelajaran. Mulyasa (2013: 42) berpenadapat bahwa pembelajaran harus sebanyak mungkin melibatkan peserta didik agar mampu bereksplorasi untuk membentuk kompetensi dengan menggali berbagai potensi dan kebenaran secara ilmiah. Dengan demikian aktivitas siswa sangat diperlukan dalam kegiatan pembelajaran, sehingga pembelajaran tersebut dapat menarik dan memberikan makna serta sebagai upaya dalam meningkatkan hasil belajar siswa. 
Shoimin (2014:21) mengemukakan pendapat bahwa inovasi pembelajaran ialah suatu yang penting dan harus dimiliki atau dilakukan oleh guru. Hal ini dikarenakan agar pembelajaran akan lebih hidup dan bermakna. Berkaitan dengan hal tersebut, perlu adanya perubahan dalam strategi pembelajaran yaitu menggunakan model pembelajaran yang tepat sesuai dengan karakteristik siswa dengan memasukan kearifan loal sebagai pendidikan karakter. Hal ini senada dengan Yudilatif (dalam Agus Wibowo dan Gunawan, 2015: 15) mengatakan bahwa pendidikan karakter mestinya berbasis pada budaya sendiri yaitu berupa peninggalan nilai-nilai luhur yang ada dalam kearifan lokal (local wisdom). Sedangkan menurut Ki Hadjar Dewantara 1977 (dalam Agus Wibowo dan Gunawan, 2015: 13) mengibaratkan pendidikan tanpa kebudayaan seperti perahu di lautan tanpa panduan arah.

Menurut Dimyati \& Mudjiono (2006:9-10) berpendapat bahwa belajar adalah suatu perilaku, ketika seseorang belajar maka responya akan baik. Sebaliknya, jika seseorang tidak belajar maka responya rendah. Hal ini berkaitan dengan permasalahan yang ditemukan di SD 2 Tenggeles yaitu guru dalam pembelajaran IPS dan Bahasa Indonesia belum menggunakan model pembelajaran yang inovatif serta belum mengkaitkan kearifan lokal daerah setempat dalam pembelajaran. Hal tersebut menyebabkan gairah belajar siswa menurun sehingga menyebabkan hasil belajar rendah. Dalam hal ini model pembelajaran mempunyai peranan penting dalam proses pembelajaran, Jadi pemilihan model pembelajaran harus disesuaikan dengan materi yang diajarkan.

Berdasarkan permasalahan diatas, solusi yang dapat digunakan untuk meningkatkan hasil belajar kognitif siswa pada pembelajaran IPS dan Bahasa Indonesia ialah dengan menggunakan model pembelajaran Make A Match berbasis kearifan lokal. Model Make A Match (mencari pasangan) merupakan salah satu jenis dari model pembelajaran cooperative learning. Murtono (2017: 39) berpendapat bahwa cooperative learning adalah rangkaian kegiatan belajar yang dilakukan oleh siswa dalam kelompok-kelompok tertentu untuk mencapai tujuan pembelajaran yang dirumuskan. Salah satu keunggulan model Make A Match ialah mencari pasangan kartu sambil mempelajari suatu konsep tertentu dalam suasana menyenangkan, sehingga tujuan pembelajaran PAKEM dapat tercapai secara efektif dan efesien.

Model pembelajaran Make A Match berbasis kearifan lokal merupakan salah satu upaya guru untuk menarik perhatian siswa sehingga dapat memupuk sikap kerjasama antar anggota kelompok, menumbuhkan kreatifitas serta keaktifan saat kegiatan pembelajaran berlangsung. Jadi dengan implementasi pembelajaran model Make A Match berbasis kearifan lokal dapat membuat siswa berfikir kritis atau Higher Order Thingking Skill (HOTS) yang sangat diperlukan pada era globalisasi ini. Siswa bukan lagi digiring untuk diberi tau, melainkan siswa harus aktif mencari tau sendiri. Berpikir kritis menuntut siswa untuk diarahkan mengingat, memahami, menerapkan, menganalisa, dan mempresentasikan hasil berfikirnya. Dengan demikian, berdasarkan paparan tersebut tujuan penelitian ini adalah untuk meningkatkan hasil belajar kognitif siswa dengan menggunakan model pembelajaran Make A Match berbasis kearifan lokal pada muatan IPS dan Bahasa Indonesia dengan ketuntasan hasil belajar klasikal 75\%. 
Implementasi Model Pembelajaran Make A Match Berbasis Kearifan Lokal Untuk Meningkatkan Hasil Belajar

\section{METODE}

Metode penelitian yang digunakan adalah penelitian tindakan kelas untuk meningkatkan hasil belajar kognitif IPS dan Bahasa Indonesia pada siswa kelas IV semester I SD 2 Tenggeles tahun pelajaran 2019/2020. Penelitian ini mulai dilakasanakan pada bulan Juli 2019 sampai dengan januari 2020 di SD 2 Tenggeles. Subjek penelitian ini adalah siswa kelas IV SD 2 Tenggeles yang berjumlah 19 orang, yang terdiri dari 7 siswa laki-laki dan 12 siswa perempuan. Alasan dalam pemilihan kelas ini ialah berdasarkan informasi hasil wawancara dengan guru kelas dan wawancara siswa terhadap rendahnya hasil belajar kognitif pada muatan pelajaran IPS dan Bahasa Indonesia. Hal ini terlihat siswa pasif dalam kegiatan kelompok, siswa berbicara sendiri saat guru menerangkan, dan sebagian siswa cenderung tidak memperhatikan guru saat kegiatan belajar mengajara berlangsung sehingga menyebabkan hasil belajar siswa rendah. Rata-rata hasil ulangan harian pertama kelas IV SD 2 Tenggeles adalah 70,52 pada muatan IPS dari 19 siswa dengan siswa tuntas 10 siswa, sedangkan untuk muatan Bahasa Indonesia 72,63 dari 19 siswa dengan siswa tuntas 12 siswa.

Prosedur penelitian yang digunakan dalam penelitian ini adalah model Kemmis \& Mc. Taggart Arikunto (2016: 16) adapun teknik pengolahan data dilakukan dengan siklus penelitian tindakan kelas secara terperinci mulai perencanaan, pelakasanaan tindakan, observasi, dan analisis refleksi yang bersifat berulang-ulang minimal 2 siklus. Berikut model penelitian tindakan kelas:

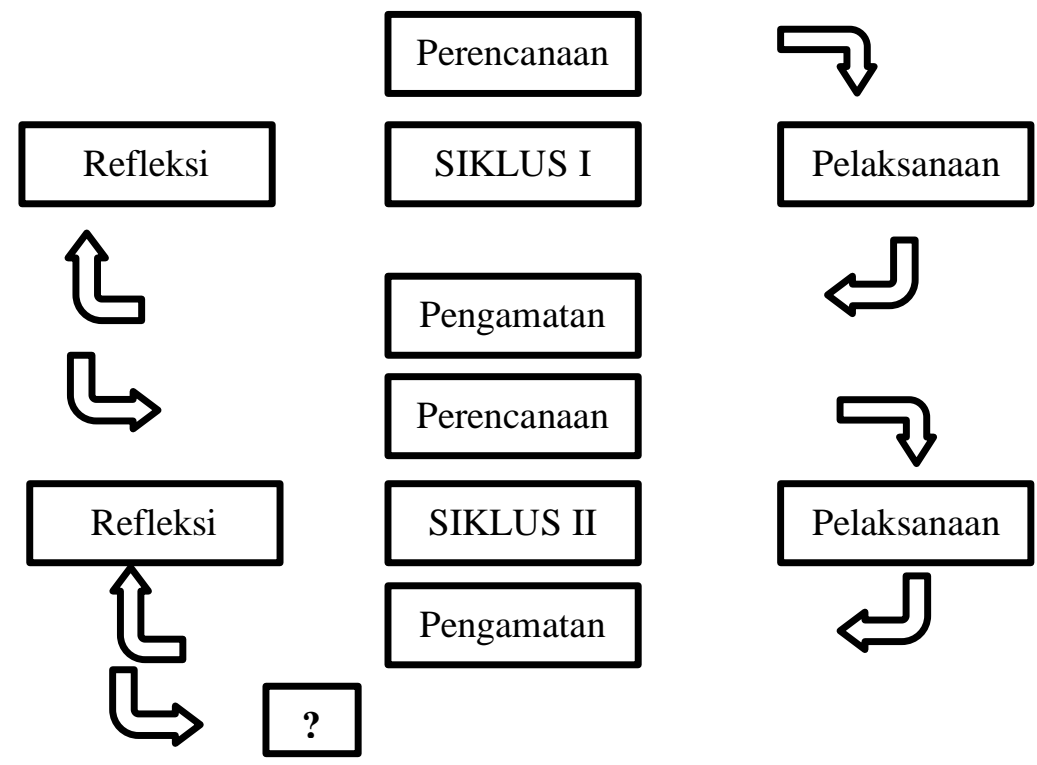

Gambar 1. Desain Penelitian Tindakan Kelas Model Kemmis \& Mc. Taggart, Arikunto (2010: 16)

1. Perencanaan Tindakan (Planning), pada tahap awal yang dilakukan adalah melakukan pengamatan terhadap proses belajar mengajar, mengidentifikasi masalah yang ditemukan saat kegiatan pembelajaran, menyiapkan dan menyusun instrument penelitian berupa silabus, RPP, dan media pembelajaran. 
2. Pelaksanaan Tindakan, pada tahapan ini peneliti menerapkan tindkan yang mengacu pada rencana diatas.

3. Observasi, kegiatan ini dilakukan dengan menggunakan lembar observasi yang telah disiapkan dan menilai hasil tindakan dengan menggunakan format penilaian.

4. Analisis dan Refleksi, dalam kegiatan ini digunakan peneliti untuk mengkaji mengenai beberapa hal yang telah dilakukan, apa yang telah dihasilkan, apa yang belum dihasilkan, dan kendala apa yang dihadapi dalam melaksanakan penelitian.

Teknik pengumpulan data yang digunakan ialah 1) observasi, untuk mengetahui sejauh mana intensitas siswa dalam berinterkasi, berkomunikasi, berkerjasama dalam kelompok serta sejauh mana siswa memperhatikan penjelasan guru. 2) wawancara, untuk melengkapai data-data yang diperlukan dalam kegiatan belajar mengajar. 3) dokumentasi, mengumpulkan catatan maupun gambar yang penting berhubungan dengan penelitian, dan 4) tes, berupa soal objektif untuk mengukur kemampuan kognitif siswa yang diperoleh dalam pembelajaran IPS dan Bahasa Indonesia dengan menggunakan model pembelajaran Make A Match berbasis kearifan lokal.

Validitas dalam penelitian ini peneliti menggunakan validitas isi dengan menggunakan expert judgment. Data tes siswa digunakan untuk mendapatkan nilai hasil belajar sisw. Tes hasil belajar yang dirancang adalah tes tertulis berbentuk tes uraian sebanyak 10 butir soal untuk tiap siklusnya yang berisi materi pelajaran yang telah dipelajari oleh siswa. Tes diberikan oleh siswa pada tiap akhir siklus. Teknik analisis data dilakukan secara deskriptif kuantitatif adalah dengan menggunakan nilai terhadap penguasaan materi pembalajarn yang telah diajarkan dan capaian hasil belajar siswa secara keseluruhan. Analisis ini juga digunakan untuk memberikan gambaran kemajuan yang diperoleh selama proses pembelajaran.

\section{HASIL}

Penelitian ini merupakan implementasi pembelajaran model Make A Match berbasis kearifan lokal untuk meningkatkan hasil belajar kognitif siswa yang dilakukan selama dua siklus. Kegiatan prasiklus merupakan sebuah kegiatan yang harus dilakukan sebelum dilaksanakannya kegiatan penelitian tindakan kelas.

\section{Hasil Prasiklus}

Berdasarkan informasi yang diperoleh dari wawancara guru kelas dan siswa kelas IV SD 2 Tenggeles pelakasanaan pembelajaran IPS dan Bahasa Indonesia belum pernah menggunakan model pembelajaran Make A Match berbasis kearifan lokal. Selama ini pembelajaran masih berjalan secara konvensional, guru mendominasi proses pembelajaran, guru menggunakan metode ceramah sehingga siswa merasa cepat bosan dalam mengikuti pembelajaran IPS dan Bahasa Indonesia. Siswa tidak diberikan kesempatan dalam 
Implementasi Model Pembelajaran Make A Match Berbasis Kearifan Lokal Untuk Meningkatkan Hasil Belajar

mengemukakan pendapat atas pertanyaan yang diajukan guru. Kondisi pembelajaran tersebut mengakibatkan hasil belajar kognitif siswa menjadi rendah. Hal ini dapat dilihat dengan nilai rata-rata tes prasiklus yang dilakukan ialah pada muatan IPS mencapai rata-rata 70,52 dengan siswa tuntas 10 siswa $(52,63 \%)$ dan siswa tidak tuntas 9 siswa $(47,36 \%)$, sedangkan pada muatan Bahasa Indonesia rata-rata mencapai 72,63 dengan siswa tuntas 12 siswa $(63,15 \%)$ dan siswa tidak tuntas 7 siswa $(36,84 \%)$.

Tabel 1.

Hasil Ulangan Prasiklus

\begin{tabular}{|l|c|c|}
\hline \multicolumn{3}{|c|}{ Hasil Belajar } \\
\hline Uraian Nilai & IPS & Bahasa Indonesia \\
\hline Rata-rata kelas & 70,52 & 72,63 \\
\hline Nilai tertinggi & 90 & 5 \\
\hline Nilai terendah & 45 & 60 \\
\hline$\geq$ KKM & $10(52,63 \%)$ & $12(63,15 \%)$ \\
\hline$<$ KKM & $9(47,36 \%)$ & $7(36,84 \%)$ \\
\hline
\end{tabular}

Berdasarkan data tabel 1 dapat disimpulkan bahwa hasil belajar prasiklus dari 19 siswa pada muatan IPS terdapat 10 siswa yang tuntas dengan presentase 52,63\% dan siswa yang tidak tuntas 9 dengan presentase 47,36\% dengan ketuntasn kategori sedang. Sedangkan pada muatan Bahasa Indonesia hasil belajar kognitif siswa dari 19 siswa terdapat 12 siswa yang tuntas dengan presentase $63,15 \%$ dan siswa yang tidak tuntas 7 siswa presentase $(36,84 \%)$.

\section{Hasil siklus I}

Berdasarkan tes hasil belajar siswa siklus I siswa yang tuntas pada muatan IPS sebanyak 13 siswa dengan presentase $68,42 \%$ sedangkan untuk muatan Bahasa Indonesia sebanyak 14 siswa presentase $73,68 \%$. Siswa yang tidak tuntas untuk muatan IPS sebanyak 6 siswa dengan presentase $31,57 \%$ dan Bahasa Indonesia 5 siswa presentase tidak tuntas $26,31 \%$.

\section{Tabel 2.}

Hasil Belajar Kognitif Siklus I

\begin{tabular}{|l|c|c|}
\hline \multicolumn{1}{|c|}{ Hasil Belajar } & IPS & Bahasa Indonesia \\
\hline Rata-rata kelas & 79,78 & 79,57 \\
\hline Nilai Tertinggi & 98 & 92 \\
\hline Nilai Terendah & 64 & 64 \\
\hline$\geq$ KKM & $13(68,42 \%)$ & $14(73,68 \%)$ \\
\hline$<$ KKM & $6(31,57 \%)$ & $5(26,31 \%)$ \\
\hline
\end{tabular}

Berdasarkan data dari tabel 2 diatas, didapat bahwa pada pembelajaran disiklus I pada muatan pelajaran IPS dan Bahasa Indonesia sudah baik karena sudah banyak siswa yang mencapai KKM 70 dengan presentase muatan IPS 68,42\% dan Bhasa Indonesia 73,68\%. Akan tetapi, siklus I belum mencapai indikator yang telah ditentukan yaitu $\geq 75 \%$ sehingga perlu adanya perbaikan pada siklus II untuk mencapai indikator keberhasilan. 


\section{Hasil Siklus II}

Berdasarkan tes belajar siswa siklus II siswa yang tuntas pada muatan IPS sebanyak 16 siswa dengan presentase $84,21 \%$ sedangkan untuk muatan Bahasa Indonesia sebanyak 17 siswa presentase tuntas $89,47 \%$. Siswa yang tidak tuntas muatan IPS sebanyak 3 siswa dengan presentase 15,75 dan Bahasa Indonesia 2 siswa presentase tidak tuntas $10,52 \%$.

\section{Tabel 3.}

Hasil Belajar Kognitif Siklus II

\begin{tabular}{|l|c|c|}
\hline \multicolumn{1}{|c|}{ Hasil Belajar Siswa } & IPS & Bahasa Indonesia \\
\hline Rata-rata Kelas & 82,63 & 83,05 \\
\hline Nilai Tertinggi & 100 & 96 \\
\hline Nilai Terendah & 68 & 68 \\
\hline$\geq$ KKM & $16(84,21 \%)$ & $17(89,47 \%)$ \\
\hline$<$ KKM & $3(15,78 \%)$ & $2(10,52 \%)$ \\
\hline
\end{tabular}

Berdasarkan data dari tabel 3 diatas bahwa pada pembelajaran siklu II pada muatan pembelajaran IPS dan Bahasa Indonesia sudah baik karena banyak siswa yang sudah mencapak KKM 70 lebih banyak dibandingkan pada siklus I dengan presentase muatan IPS 84,21\% dan Bahasa Indonesia $89,47 \%$. Hal ini menunjukkan bahwa presentase siswa tuntas sudah mencapai indikator ketuntasan klasikal yang telah ditentukan yaitu $\geq 75 \%$.

Penelitian dilakukan dengan menggunakan dua siklus menggunakan model yang sama yaitu model pembelajarn Make A Match berbasis kearifan lokal. Dari hasil analisis hasil belajar siswa yang diperoleh dari pelakasanaan tes evaluasi dengan 10 tes soal uraian yang diberikan kepada siswa di setiap akhir siklusnya terbukti mampu meningkatkan hasil belajar kognitif siswa. Peningkatan nilai hasil belajar siswa dapat dilihat pada tabel 4 dan grafik pada gambar 1 .

\section{Tabel 4.}

Rekapitulasi Peningkatan Hasil Belajar Kognitif Siswa Prasiklus, Siklus I, dan Siklus II

\begin{tabular}{|l|c|c|c|c|c|c|}
\hline \multirow{3}{*}{ Uraian Nilai } & \multicolumn{6}{|c|}{ Hasil Belajar Kognitif Siswa } \\
\cline { 2 - 7 } & \multicolumn{2}{|c|}{ Prasiklus } & \multicolumn{2}{c|}{ Siklus I } & \multicolumn{2}{c|}{ Siklus II } \\
\cline { 2 - 7 } & IPS & $\begin{array}{c}\text { Bahasa } \\
\text { Indonesia }\end{array}$ & IPS & $\begin{array}{c}\text { Bahasa } \\
\text { Indonesia }\end{array}$ & IPS & $\begin{array}{c}\text { Bahasa } \\
\text { Indonesia }\end{array}$ \\
\hline Nilai Terendah & 45 & 60 & 64 & 64 & 68 & 68 \\
\hline Nilai Tertinggi & 90 & 85 & 98 & 92 & 100 & 96 \\
\hline Rata-rata & 70,52 & 72,63 & 79,78 & 79,57 & 82,63 & 83,05 \\
\hline Ketuntasan & 10 & 12 & 13 & 14 & 16 & 17 \\
\hline $\begin{array}{l}\text { Persen } \\
\text { Ketuntasan }\end{array}$ & $52,63 \%$ & $63,15 \%$ & $68,42 \%$ & $73,68 \%$ & $84,21 \%$ & $89,47 \%$ \\
\hline
\end{tabular}

Berdasarkan pada tabel 4 diatas, pencapaian nilai rata-rata hasil tes tiap siklus mengalami peningkatan. Hasil ini terlihat dari nilai rata-rata dan persen ketuntasan siswa. 


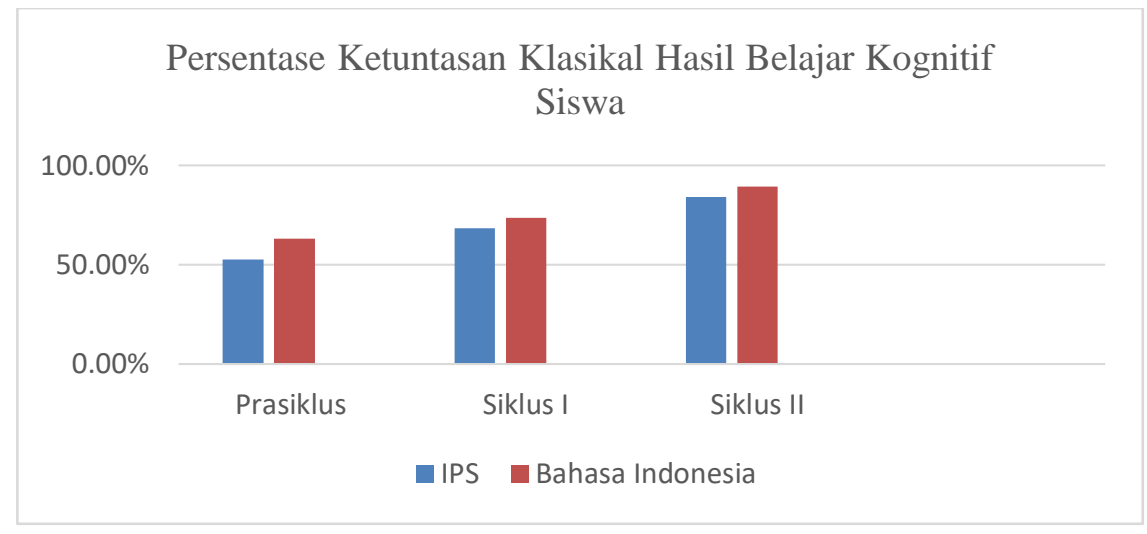

Gambar 2. Persentase ketuntasan klasikal hasil belajar kognitif siswa

Berdasarkan gambar 2 tersebut, dalam penerapan model Make A Match berbasis kearifan lokal terdapat temuan diantaranya sebagai berikut. Secara umum hasil belajar siswa sudah meningkat dari pratindakan, siklus I, dan siklus II, jika dilihat dari gambar 1 menunjukkan bahwa prasiklus mengalami peningkatan dari 52,63\%, selanjutnya untuk siklus I 68,42\% dan $84,21 \%$ siklus II untuk muatan IPS. Sedangkan pada muatan Bahasa Indonesia mengalami peningkatan prasiklus dari $68,15 \%$, selanjutnya $73,68 \%$ untuk siklus I, dan $89,47 \%$ siklus II. Dengan demikian dapat menjadi indikator keberhasilan dari implementasi model pembelajaran Make A Match berbasis kearifan lokal untuk meningkatkan hasil belajar kognitif siswa. Hal ini sejalan dengan penelitian yang telah dilakukan Tiballa (2017) mengemukakan pendapat bahwa Make A Match adalah suatu model pembelajaran yang berhubungan dengan karakteristik siswa dimana pada pembelajaran ini siswa menjadai lebih aktif untuk memecahkan permsalahan yang diberikan guru sehingga hasil belajar siswa meningkat.

Hasil penelitian ini diperkuat oleh penelitian yang telah dilakukan oleh Nuzmi'ah (2016) bahwa hasil penelitian yang dilakukannya terdapat peningkatan hasil belajar aspek kognitif yang setiap siklusnya mengalami peningkatan yang signifikan, dari data $74,75 \%$ menjadi $82,62 \%$. Sehingga dapat disimpulkan bahwa model penggunaan model Make A Match berbasis kearifan lokal layak digunakan untuk meningkatkan hasil belajar siswa. Berdasarkan pembahasan diatas, dapat di simpulkan bahwa pada siklus II hasil belajar kognitif siswa mengalami peningkatan signifikan dibandingkan prasiklus dan siklus I. Dengan demikian, hal tersebut menunjukkan dengan implementasi model pembelajaran Make A Match berbasis kearifan lokal pada kelas IV SD 2 Tenggeles mampu meningkatkan hasil belajar kognitif siswa dengan baik.

\section{KESIMPULAN}

Berdasarkan hasil penenlitian dan pembahasan yang diperoleh dari implementasi model pembelajaran Make A Match berbasis kearifan lokal pada pembelajaran IPS dan Bahasa Indonesia kelas IV SD 2 Tenggeles di Kabupaten Kudus dapat disimpulkan sebagai berikut. Pada siklus I dari 
19 siswa yang tuntas ada 13 siswa dan yang tidak tuntas ada 6 siswa dengan persentase ketuntasan 68,42\% untuk muatan IPS, selanjutnya pada muatan Bahasa Indonesia siklus I siswa yang tuntas 14 dari 19 siswadan tidak tuntas 5 dengan persentase tuntas 73,68\%. Hasil belajar kognitif siswa muatan IPS pada siklus II siswa yang tuntas 16 dan yang tidak tuntas 3 dari 19 siswa memperoleh persentase $84,21 \%$. Sedangkan untuk muatan Bahasa Indonesia siklus II siswa tuntas 17 dan siswa yang tidak tuntas 2 siswa dari 19 siswa dengan persentase 89,47\% adanya peningkatan siklus I ke siklus II sudah mencapai indikator keberhasilan karena batas minimal ketuntasan minimal klasikal yaitu 75\%.

Berdasarkan uraian hasil penelitain dan pembahasan serta simpulan yang telah disampaikan, maka beberapa saran yang dapat diberikan sebagai berikut. Pertama, saran untuk guru adalah: 1) memberikan kebebasan kepada siswa untuk berkerjasama, mengeksplorasi segenap kemampuannya dan bentuk keingintahuannya dalam bentuk diskusi; 2) menggunakan model pembelajaran Make A Match berbasis kearifan lokal sebagai model pembelajarn yang aktif, kreatif, efektif dan menyenangkan; 3) lebih kreatif dalam membuat maupun menggunakan model pembelajaran.

Kedua, kepada sekolah hendaknya memberikan sosialisasi kepada semua guru untuk meningkatkan mutu pendidikan dengan cara dalam kegiatan pembelajaran perlu adanya pembelajaran yang kreatif untuk meningkatakan hasil belajar siswa. Seperti menggunakan model pembelajaran Make A Match berbasis kearifan lokal yang sudah terbukti dapat meningkatkan hasil belajar siswa. Sekolah hendaknya juga memperhatikan sarana dan prasarana sekolah dalam menunjang proses kegiatan pembelajaran.

Ketiga kepada siswa untuk, 1) selalu aktif dan antusias mengikuti pembelajaran karena dengan aktif siswa dapat memiliki minat tinggi dalam pembelajaran sehingga pembelajaran berhasil; 2) siswa diharapkan mempunyai kesadaran dalam belajar untuk kepentingan diri siswa; 3) siswa dapat berperan aktif dalam menyampaikan ide atau pemikiran pada proses pembelajaran, sehingga proses pembelajaran dapat berjalan dengan lancer dan mendapatkan hasil yang optimal.

Keempat kepada peneliti lain yang ingin melakukan penelitian hendaknya terlebih dahulu menganalisis model untuk disesuaikan dengan penerapannya, alokasi waktu yang tepat, fasilitas pendukung dan karakteristik siswa pada sekolah tempat penelitian dilakukan. Serta diharapkan bagi peneliti selanjutnya dapat menerapkan model pembelajaran lain, sehingga dapat memperoleh solusi baru untuk meningkatkan hasil belajar kognitif siswa serta mampu mengarahkan setiap kegiatan pembelajaran agar siswa dapat aktif dan pemebalajaran berlangsung secara efektif dan efisien.

\section{DAFTAR PUSTAKA}

Anggarawati, Aru \& dkk. 2014. Pengaruh Make A Match Berbantuan Media Kartu Gambar Terhadap Hasil Belajar IPS SD. PGSD Vol: 2 No: 1 Tahun 2014.

Arikunto, Suharsimi. 2016. Prosedur Penelitian: Suatu Pendekatan Praktik. Jakarta: Rineka Cipta. Daryanto dan Mulyo Rahadjo. 2012. Model Pembelajaran Inovatif. Yogyakarta: Gava Media. 
Implementasi Model Pembelajaran Make A Match Berbasis Kearifan Lokal Untuk Meningkatkan Hasil Belajar

Dimyati dan Mudjiono. 2006. Belajar dan Pembelajaran. Jakarta: Rineka Cipta.

Dwi Sana Tiballa, Meida \& dkk. Pengaruh Model Pembelajaran Kooperatif Tipe Make A Match Berbantuan Peta Pikiran Terhadap Hasil Belajar IPA Siswa Kelas V Sekolah Dasar. Mimbar PGSD Vol: 5 No: 2 Tahun 2017.

Gunawan dan Agus Wibowo. 2015. Pendidikan Karakter Berbasis Kearifan Lokal di Sekolah. Yogyakarta: Pustaka Belajar.

Khanifa, dkk. 2012. Pemanfaatan Lingkungan Sekolah Sebagai Sumber Belajar untuk Meningkatkan Hasil Belajar Siswa. Semarang: Universitas Negeri Semarang. Unnes Journal of Biology Education ISSN 22526579.

Mulyasa. 2013. Pengembangan Implementasi Kurikulum 2013. Banadung: PT Remaja Rosdakarya Offset.

Murtono. 2017. Model-Model Pembelajaran Inovatif. Jawa Timur: Wade Group.

Nafisah, Vanya \& dkk. 2017. Pengaruh Model Pembelajaran Kooperatif Tipe Make A Match untuk Meningkatkan Hasil Belajar Siswa pada Materi Jenis-Jenis Pekerjaan di SD. Vol. 4, No. 2 (2017) 199-207.

Nuzmi'ah, Ana. 2016. Peningkatan Motivasi dan Hasil Belajar Siswa melalui Model Pembelajaran Snowball Throwing pada Pembelajaran IPS di SDN Sawojajar 04 Kota Malang. Volume 5, No 2 Agustus 2016.

Shoimin, Aris. 2014. 68 Model Pembelajaran Inovatif dalam Kurikulum 2013. Yogyakarta: Ar-Ruzz Media. 